\title{
П'ятирічна загальна виживаність та виживаність без прогресування при застосуванні пембролізумабу у пацієнтів із поширеним НДРЛ
}

DOI: $10.32471 /$ clinicaloncology.2663-466X.39-3.27558

\begin{abstract}
У даному огляді представлено оновлені результати клінічного дослідження III фази KEYNOTE-024, у ході якого вивчається ефективність та профіль безпеки пембролізумабу в порівнянні із хіміотерапією в якості I лінії терапії пацієнтів із поширеним недрібноклітинним раком легені. Так, наведено дані щодо 5-річної загальної виживаності пацієнтів, що отримували пембролізумаб, які були представлені на Віртуальному конгресі Європейського суспільства медичної онкології (Еuropean Society for Medical Oncology - ESMO) 21 вересня 2020 р., а також результати субаналізу японської популяції пацієнтів щодо виживаності без прогресування, опубліковані 14 вересня 2020 р. у журналі «Cancer Science».
\end{abstract}

Ключові слова: НДРЛ; пембролізумаб; 5-річна загальна виживаність; ESMO.

\section{ВстУП}

Рак легені є основною причиною смертності від раку у всьому світі. Хіміотерапія на основі платини історично була стандартним методом лікування I лінії для пацієнтів на пізніх стадіях недрібноклітинного раку легені (НДРЛ), особливо без мутацій $E G F R$ та $A L K 3-5$; однак імунотерапія, спрямована на PD-1, нещодавно надала пацієнтам терапевтичний варіант, який може покращити клінічні результати порівняно зі стандартними схемами хіміотерапії [1]. Імунотерапія пембролізумабом є методом лікування I лінії для пацієнтів з метастатичним НДРЛ без мутацій цільових генів та з рівнем експресії пухлиною PD-L1 за шкалою пропорції пухлини (tumor proportion score - TPS) 50\% або вище [2].

Пембролізумаб є гуманізованим моноклональним антитілом, що блокує взаємодію між рецептором запрограмованої смерті клітин-1 (programmed cell death-1 - PD-1) та лігандами рецептора запрограмованої смерті клітин-1 і -2 (programmed cell death-ligand-1, -2 - PD-L1, PD-L2), запускаючи інгібування імунної відповіді, опосередкованої PD-1, включаючи протипухлинну імунну відповідь. Зв'язування PD-L1 i PDL2 із рецептором PD-1, що міститься у T-клітинах, інгібуе проліферацію Т-клітин і продукцію цитокінів. Активізація PD-1 ліганда відбувається у деяких пухлинах, і передача сигналів цим шляхом може спричиняти гальмування активного Т-лімфоцитарного контролю пухлин [3, 4].

Клінічне дослідження I фази KEYNOTE-001 стало першою роботою, у якій було продемонстровано наявність асоціації між експресією PD-L1 та відповіддю на застосування пембролізумабу і показало вищий рівень відповіді серед пацієнтів із поширеним НДРЛ та високим рівнем PD-L1 (TPS 50\% або вище) [5]. У глобальному клінічному дослідженні III фази KEYNOTE-024 було виявлено, що у пацієнтів з раніше нелікованим метастатичним НДРЛ без активуючих мутацій $E G F R$ або транслокацій ALK та з високим рівнем PD-L1 (TPS 50\% або вище) було відмічено значно кращу загальну виживаність (3В) (відношення ризиків (ВР) 0,$60 ; 95 \%$ довірчий інтервал (ДІ) $0,41-0,89 ; \mathrm{p}=0,005)$ та сприятливі результати щодо профілю безпеки під час застосування пембролізумабу порівняно з препаратами платини в складі хіміотерапії [6]. Попередній аналіз KEYNOTE -024 показав, що застосування пембролізумабу дозволяло продовжити 2-річну 3В порівняно з хіміотерапією (ВР 0,$63 ; 95 \%$ ДІ 0,47-0,86; p=0,002), незважаючи на збільшення кількості пацієнтів, які перейшли з хіміотерапії на пембролізумаб (82 хворих порівняно з 66 пацієнтами, які перейшли на пембролізумаб у дослідженні в попередньому аналізі) [7].

У дослідження KEYNOTE-024 включали дорослих пацієнтів віком від 18 років з раніше нелікованим НДРЛ IV стадії без активуючих мутацій $E G F R$ або транслокацій ALK, з високим рівнем експресії PD-L1 пухлиною (TPS $\geqslant 50 \%$ ), у яких відмічали захво- рювання, що оцінювалося за Критеріями оцінки об’єктивного відбору при солідних пухлинах, версія 1.1 (Response Evaluation Criteria in Solid Tumors v1.1 - RECIST version 1.1) та загальним станом онкологічного хворого за шкалою Східної кооперативної онкологічної групи (Eastern Cooperative Oncology Group - ECOG) як 0 або 1. Для оцінки рівня PD-L1 пацієнти повинні були надати зразок тканини пухлини, отриманий під час або після діагностики метастатичного захворювання, перед будь-якою ад'ювантною або неоад'ювантною терапією. Хворі не відповідали вимогам, якщо у них були неліковані метастази у мозку, активне аутоімунне захворювання, що вимагало системного лікування, вони отримували системну стероїдну терапію протягом 3 днів до першої дози досліджуваного препарату або отримували будь-які інші імунодепресивні ліки чи мали інтерстиціальне захворювання легенів або пневмоніт в анамнезі, який слід було лікувати стероїдами [6].

Пацієнтів випадковим чином розподілили у співвідношенні 1:1 для отримання або пембролізумабу 200 мг внутрішньовенно кожні 3 тиж протягом 35 циклів, або хіміотерапії на вибір дослідника однієї з 5 схем на основі платини, обраних до рандомізації, протягом 4-6 циклів: карбоплатин або цисплатин плюс пеметрексед; карбоплатин або цисплатин плюс гемцитабін або карбоплатин плюс паклітаксел [6]. Схеми, що містять пеметрексед, були дозволені лише пацієнтам з неплоскоклітинним НДРЛ, а підтримувальна терапія пеметрекседом могла продовжуватися після завершення комбінованої схеми хіміотерапії. Рандомізацію стратифікували за показником ефективності ECOG (0 проти 1) та гістологією пухлини (плоско- проти неплоскоклітинного). Лікування продовжувалося із застосуванням заздалегідь визначеної кількості циклів або до рентгенологічного прогресування захворювання згідно з RECIST, версія 1.1, на думку дослідника, або через неприпустиму токсичність, супутні хвороби, що виключають подальше лікування, або пацієнтом чи дослідником було прийнято рішення про припинення терапії. Перехід від хіміотерапії до пембролізумабу дозволявся пацієнтам із задокументованим прогресуванням захворювання (згідно 3 RECIST, версія 1.1), які відповідали критеріям безпеки. Пацієнти в обох групах лікування, які вважалися такими, що будуть мати клінічну користь і були клінічно стабільними (тобто відсутність ознак та симптомів клінічно значущого прогресування, швидкого прогресування захворювання або прогресування, що вимагає невідкладного альтернативного лікування, і відсутність зниження рівня ECOG), продовжували отримувати лікування після прогресування хвороби. Пацієнти в групі пембролізумабу, які досягли повної відповіді, могли припинити терапію, якщо вони лікувалися принаймні 6 міс і отримували принаймні 2 курси лікування після початкової дати повної відповіді [6]. Пацієнти, які припинили застосування пембролізумабу після повної відповіді або завершення 
лікування пембролізумабом через 2 роки (35 циклів) могли згодом, після прогресування захворювання, пройти наступний курс пембролізумабу, що включав до 17 циклів, якщо вони не отримували жодної протипухлинної терапії з моменту останньої дози пембролізумабу та продовжували відповідати необхідним критеріям прийнятності.

Первинною кінцевою точкою в дослідженні KEYNOTE-024 була виживаність без прогресування (ВБП) захворювання, яка визначалася як час від рандомізації до першого задокументованого прогресування захворювання (згідно з RECIST 1.1) або до смерті з будь-якої причини. Вторинними кінцевими точками були ЗВ, що визначалися як час від рандомізації до смерті з будь-якої причини; рівень об’єктивної відповіді, що визначався як частка пацієнтів із підтвердженою повною або частковою відповіддю (згідно з RECIST 1.1) та профіль безпеки. Тривалість відповіді була дослідницькою кінцевою точкою та визначалася як час від першої задокументованої повної або часткової відповіді до прогресування захворювання [6].

\section{ESMO: 5-РІЧНА ЗВ ПІД ЧАС ЗАСТОСУВАННЯ ПЕМБРОЛІЗУМАБУ В ЯКОСТІ І ЛІНІЇ ТЕРАПІЇ У ПАЦІЄНТІВ ІЗ ПОШИРЕНИМ НДРЛ}

На щорічному конгресі Європейського товариства медичної онкології (European Society for Medical Oncology - ESMO) були представлені оновлені дані щодо ефективності та профілю безпеки пембролізумабу за результатами 5 років спостережень у ході клінічного дослідження KEYNOTE-024 [8].

У період з 19 вересня 2014 р. до 29 жовтня 2015 р. в цілому 305 пацієнтів у 102 лікувальних закладах, які відповідали критеріям включення, були рандомізовані до групи пембролізумабу (154 пацієнти) або групи хіміотерапії (151 пацієнт). Станом на 1 червня 2020 р. медіана (діапазон) часу від рандомізації до аналізу даних становила $59,9(55,1-68,4)$ міс. Відповідно до отриманих результатів $83(55,0 \%)$ пацієнти, рандомізовані до групи, що отримувала хіміотерапію, змінили лікування на застосування пембролізумабу. Ефективність у популяції хворих, що отримували лікування пембролізумабом, та у 39 з 154 (25,3\%) пацієнтів з групи пембролізумабу, які пройшли 35 циклів терапії, показані в таблиці. Крім того, 12 із 154 пацієнтів розпочали другий курс пембролізумабу; результати цих хворих також представлені в таблиці. Серед усіх пацієнтів, що отримували пембролізумаб, частота випадків небажаних явищ 3-5-го ступенів, пов'язаних із лікуванням, становила $31,2 \%$ при застосуванні пембролізумабу порівняно з 53,3\% при хіміотерапії.

Таким чином, пембролізумаб продовжує демонструвати покращення 3В у порівнянні із хіміотерапією в якості I лінії

Таблиця. Ефективність застосування пембролізумабу порівняно із хіміотерапією

\begin{tabular}{lcc}
\hline & $\begin{array}{c}\text { Пембролізумаб } \\
(\mathbf{n = 1 5 4 )}\end{array}$ & $\begin{array}{c}\text { Хіміотерапія } \\
\text { (n=151) }\end{array}$ \\
\hline Медіана 3В, міс (ДІ 95\%) & $26,3(18,3-40,4)$ & $13,4(9,4-18,3)$ \\
- ВР (ДІ 95\%) & $0,62(0,48-0,81)$ & 16,3 \\
Оцінка 5-річної & 31,9 & \\
3В за Каплан - Мейєром, \% & $\begin{array}{c}\text { Пацієнти, які отри- } \\
\text { мали } 35 \text { циклів лі- } \\
\text { кування (n=39) } \\
\text { Р2 }\end{array}$ \\
Рівень об'єктивної відповіді на ліку- & $32,1)$ \\
вання, $\mathbf{n}(\%)^{\text {a }}$ & \\
- Повна відповідь & $4(10,3)$ \\
- Часткова відповідь & $28(71,8)$ \\
- Стабілізація захворювання & $6(15,4)$ \\
Пацієнти, що на момент аналізу & $32 / 39(82,1)^{6}$ \\
були живі, п/N (\%) & \\
Попередня оцінка 3-річної 3В за Ка- & 81,4 \\
план - Мейєром після завершення & \\
застосування пембролізумабу, \% & \\
\hline
\end{tabular}

ана момент проведення аналізу 18 з 39 пацієнтів були живими і не мали прогресування захворювання за оцінкою дослідника; 67 пацієнтів померли через прогресування захворювання; 2 не отримували жодного додаткового лікування. терапії метастатичного НДРЛ у пацієнтів з високим рівнем PD-L1 (TPS $\geqslant 50 \%)$. Незважаючи на високий коефіцієнт переведення пацієнтів з одного лікування на інше, 5-річна ЗВ була приблизно вдвічі більшою серед тих, хто отримував пембролізумаб порівняно із хіміотерапією (31,9\% проти $16,3 \%)$. У меншої кількості пацієнтів, які отримували пембролізумаб, спостерігалися небажані явища 3-5-го ступенів порівняно із тими, хто отримував хіміотерапію.

\section{ВИЖИВАНІСТЬ БЕЗ ПРОГРЕСУВАННЯ ЗА РЕЗУЛЬТАТАМИ ЯПОНСЬКОГО СУБАНАЛІЗУ KEYNOTE-024}

Даний попередній субаналіз глобального рандомізованого контрольованого дослідження III фази KEYNOTE-024 включає клінічні результати пацієнтів, які були набрані у дослідження в Японії. 3305 хворих, рандомізованих у рамках дослідження KEYNOTE-024, 40 пацієнтів було включено в дослідження в Японії (усі отримували лікування: пембролізумаб, $\mathrm{n}=21$; хіміотерапія, $\mathrm{n}=19$ ).

Загальна кількість випадків прогресування захворювання становила 27 із 40 пацієнтів, серед яких лише 10 належали до групи, що отримувала пембролізумаб. Медіана ВБП становила 41,4 міс (ДІ 95\% 4,2-42,5) у групі пацієнтів, що отримували пембролізумаб, та 4,1 міс (ДІ 95\% 2,8-8,3) у групі хворих, яким призначали хіміотерапію (ВР для ВБП 0,27; 95\% ДІ 0,11-0,65; $\mathrm{p}=0,001)$. Крім того, передбачуваний рівень ВБП через 1 рік був вищим у групі пембролізумабу (64\% [95\% ДІ 39-81\%]) порівняно з групою хіміотерапії (25\% [95\% ДІ 9-46\%]).

На момент аналізу даних близько половини пацієнтів померли (у групі пембролізумабу n=9; у групі хіміотерапії $\mathrm{n}=14$ ). Медіана 3В не була досягнута (НД) (ДІ 95\% 22,9НД) та 21,5 (95\% ДІ 5,2-35,0) міс відповідно (ВР 0,39 [95\% ДІ $0,17-0,91] ; p=0,012)$. Прогнозовані показники 3В у групі пембролізумабу порівняно з групою хіміотерапії становили $86 \%$ (95\% ДІ 62-95\%) проти 63\% (95\% ДІ 38-80\%) через 1 рік, $71 \%$ (95\% ДІ $47-86 \%$ ) проти $37 \%$ (95\% ДІ 17-58\%) через 2 роки та $67 \%$ (95\% ДІ 43-83\%) проти 26\% (95\% ДІ 10-47\%) через 3 роки спостереження.

Рівень об'єктивної відповіді становив 62\% (95\% ДІ 38-82\%) у групі пембролізумабу та 26\% (95\% ДІ 9-51\%) у групі хіміотерапії $(\mathrm{p}=0,019)$. Медіана тривалості відповіді не була визначена (від $6,2+$ до $20,6+$ міс) у групі пембролізумабу та становила 9,8 міс (від 4,8+ до 10,4 міс) у групі хіміотерапії (знак плюс в діапазонах вказує на прогресування захворювання при останньому огляді для пацієнта з мінімальною/максимальною тривалістю відповіді). Серед пацієнтів у групі пембролізумабу, які мали повну $(\mathrm{n}=1)$ або часткову $(\mathrm{n}=12)$ відповідь, 7 пройшли 35 циклів ( 2 роки) лікування на момент аналізу даних. Із цих 7 пацієнтів 3 отримали другий курс пембролізумабу (один завершив 17 циклів, а другий припинив через прогресування хвороби; усі троє залишалися живими на момент аналізу даних).

Побічні реакції, пов’язані з лікуванням, будь-якого ступеня спостерігалися у всіх 21 пацієнта, які отримували пембролізумаб, та 18 з 19 пацієнтів (95\%), які отримували хіміотерапію в цій японській когорті пацієнтів. Найпоширенішими небажаними явищами, пов'язаними з лікуванням, у групі пембролізумабу були пірексія $(\mathrm{n}=5)$, діарея $(\mathrm{n}=4)$ та висип $(\mathrm{n}=4)$, а найчастішим у групі хіміотерапії було зниження апетиту $(\mathrm{n}=12)$, нудота $(\mathrm{n}=11)$ та анемія $(\mathrm{n}=9)$. Побічні ефекти, пов'язані з лікуванням, 3-5-го ступеня спостерігалися у 8 пацієнтів (38\%) у групі пембролізумабу та у 9 хворих (47\%) групи хіміотерапії. 4 пацієнти (19\%) у групі пембролізумабу та 1 хворий (5\%) групи хіміотерапії припинили лікування через пов'язані з лікуванням небажані явища. Жоден пацієнт у групі пембролізумабу не помер через небажані явища, пов'язані з лікуванням, у групі хіміотерапії з цієї причини помер 1 пацієнт (5\%). Імуноопосередковані небажані явища та реакції в місці інфузії будь-якого ступеня та незалежно від ставлення до лікування, за оцінкою дослідника, відмічали у 11 пацієнтів (52\%) у групі, яка отримувала пембролізумаб, та у 4 хворих (21\%) 
групи хіміотерапії. Найбільш частими подіями в групі пембролізумабу (які спостерігалися щонайменше у $10 \%$ пацієнтів) були реакції в місці інфузії $(\mathrm{n}=4 ; 19 \%)$, а також пневмоніт та гіпотиреоз (кожен $n=3 ; 14 \%$ ). Імуноопосередковані небажані явища 3-5-го ступенів спостерігалися у 4 пацієнтів (19\%) у групі пембролізумабу (гепатит 3-го ступеня, тяжка шкірна реакція, увеїти та пневмоніт 4-го ступеня, все у одного пацієнта) та у 1 пацієнта (5\%) в групі хіміотерапії (пневмоніт 3-го ступеня).

Цей попередній субаналіз KEYNOTE-024 показав, що пембролізумаб подовжував ВБП порівняно із хіміотерапією на основі платини у японських пацієнтів з раніше нелікованим метастатичним НДРЛ без активуючих мутацій $E G F R$ або транслокації ALK та високого рівня PD-L1 (TPS 50\% або більше). Лікування пембролізумабом асоціювалося з вищим рівнем об'єктивної відповіді порівняно з хіміотерапією (62 проти 26\%). Крім того, пембролізумаб мав керований профіль безпеки, і в цій підгрупі японських пацієнтів не було виявлено нових небажаних реакцій у порівнянні з попередніми дослідженнями, у ході яких вивчався профіль безпеки монотерапії пембролізумабом у пацієнтів із поширеним НДРЛ. Отримані результати щодо переваги монотерапії пембролізумабом щодо ВБП узгоджуються з результатами отриманими в загальній популяції пацієнтів у рамках дослідження у KEYNOTE-024 [5, 6, 9].

\section{висновки}

Успішні результати аналізу найновіших даних, отриманих у рамках клінічного дослідження KEYNOTE-024, узгоджуються з попередніми позитивними висновками зробленими за підсумками великого багатоцентрового рандомізованого контрольованого дослідження III фази KEYNOTE-042 [10]. Peзультати, отримані в ході дослідження KEYNOTE-024, узгоджуються з висновками зробленими на основі даних дослідження KEYNOTE-042, що продемонструвало переваги застосування пембролізумабу шодо ЗВ порівняно із хіміотерапією на основі платини у пацієнтів з раніше нелікованим локально прогресуючим або метастатичним НДРЛ без активуючих мутацій $E G F R$ або транслокацій ALK та високим рівнем PD-L1 (TPS 50\% або вище). Значні переваги щодо ЗВ також виявлені під час застосування пембролізумабу та хіміотерапії на основі платини у порівнянні тільки з хіміотерапією у пацієнтів з метастатичним НДРЛ без активуючих мутацій EGFR або транслокацій ALK, незалежно від рівня експресії PD-L1, які раніше не лікувалися, у плацебоконтрольованих дослідженнях III фази KEYNOTE-189 (неплосколітинний рак; ВР 0,49; p<0,001) та KEYNOTE-407 (плоскоклітинний рак; ВР 0,$64 ; \mathrm{p}<0,001)[11,12]$.

Підводячи підсумки слід зазначити, що наведені результати дослідження KEYNOTE-024 продемонстрували ефективність та переваги пембролізумабу порівняно із хіміотерапією на основі платини щодо ВБП, рівня об'єктивної відповіді та 3В. Ці висновки свідчать про обгрунтованість застосування монотерапії пембролізумабом у якості І лінії терапії у пацієнтів з метастатичним НДРЛ без активуючих мутацій EGFR або транслокацій ALK з високим рівнем PD-L1 (TPS 50\% або вище).

\section{Пятилетняя общая выживаемость \\ и выживаемость без прогрессирования при применении пембролизумаба у пациентов с распространенным НМРЛ}

В данном обзоре представлены обновленные результаты клинического исследования III фазы KEYNOTE-024, в ходе которого изучается эффективность и профиль безопасности пемб- ролизумаба по сравнению с химиотерапией в качестве I линии терапии пациентов с распространенным немелкоклеточным раком легкого. Так, приведены данные относительно 5-летней общей выживаемости пациентов, получавших пембролизумаб, которые были представлены на Виртуальном конгрессе Европейского общества медицинской онкологии (European Society for Medical Oncology - ESMO) 21 сентября 2020 г., а также результаты субанализа японской популяции пациентов по выживаемости без прогрессирования, опубликованные 14 сентября 2020 г. в журнале «Cancer Science».

Ключевые слова: НМРЛ; пембролизумаб; 5-летняя общая выживаемость; ESMO.

Five-year overall survival and progression-free survival of patients with advanced NSCLC receiving pembrolizumab

This review will present the latest updated results of the KEYNOTE-024 phase III clinical trial examining the efficacy and safety profile of pembrolizumab compared with chemotherapy as a first-line treatment for patients with advanced non-small cell lung cancer (NSCLC). There are data on the 5-year overall survival of patients receiving pembrolizumab, which were presented at the Virtual Congress of the European Society of Medical Oncology (ESMO) on September 21, 2020, as well as the results of subanalysis of the Japanese patient population for survival without progression published on September 14, 2020 in the journal Cancer Science.

Key words: NSCLC; pembrolizumab; 5-year overall survival; ESMO.

\section{СПИСОК ВИКОРИСТАНОÏ ЛІТЕРАТУРИ}

1. Bray, F., Ferlay, J., Soerjomataram, I., Siegel, R. L., Torre, L. A., \& Jemal, A. (2018). Global cancer statistics 2018: GLOBOCAN estimates of incidence and mortality worldwide for 36 cancers in 185 countries. CA: a cancer journal for clinicians, 68(6), 394-424.

2. Akamatsu, H., Ninomiya, K., Kenmotsu, H., et al. (2019). The Japanese Lung Cancer Society Guideline for non-small cell lung cancer, stage IV. Int J Clin Oncol., $24,731-770$

3. Amrane, K., Geier, M., Corre, R., Léna, H., Léveiller, G., Gadby, F.,... \& Gouva, S. (2020). First-line pembrolizumab for non-small cell lung cancer patients with PD-L1》 $50 \%$ in a multicenter real-life cohort: The PEMBREIZH study. Cancer Medicine, 9(7), 2309-2316.

4. Peters, S., Kerr, K. M., \& Stahel, R. (2018). PD-1 blockade in advanced NSCLC: a focus on pembrolizumab. Cancer treatment reviews, 62, 39-49.

5. Garon, E. B., Rizvi, N. A., Hui, R., Leighl, N., Balmanoukian, A. S., Eder, J. P., \& Carcereny, E. (2015). Pembrolizumab for the treatment of non-small-cell lung cancer. New England Journal of Medicine, 372(21), 2018-2028.

6. Reck, M., Rodríguez-Abreu, D., Robinson, A. G., Hui, R., Csőszi, T., Fülöp, A.,... \& O'Brien, M. (2016). Pembrolizumab versus chemotherapy for PD-L1-positive non-small-cell lung cancer. $N$ engl $J$ med, 375, 1823-1833.

7. Reck, M., Rodríguez-Abreu, D., Robinson, A., Hui, R., Csoszi, T., Fulop, A., ... \& O'Brien, M. (2019). Updated analysis of KEYNOTE-024: pembrolizumab versus platinumbased chemotherapy for advanced non-small-cell lung cancer with PD-L1 tumor proportion score of $50 \%$ or greater. J Clin Oncol., 37, 537-546.

8. J.R. Brahmer, J. R., Rodriguez-Abreu, D., Robinson, A. G., Hui, R., Csőszi, T., Fülöp, A., ... \& O'Brien, M. (2020). LBA51 KEYNOTE-024 5-year OS update: First-line (1L) pembrolizumab (pembro) vs platinum-based chemotherapy (chemo) in patients (pts) with metastatic NSCLC and PD-L1 tumour proportion score (TPS) $\geqslant 50 \%$. Annals of Oncology, 31, S1181-S1182.

9. Herbst, R. S., Baas, P., Kim, D. W., Felip, E., Pérez-Gracia, J. L., Han, J. Y., .. \& Majem, M. (2016). Pembrolizumab versus docetaxel for previously treated, PD-L1positive, advanced non-small-cell lung cancer (KEYNOTE-010): a randomised controlled trial. The Lancet, 387(10027), 1540-1550.

10. Mok, T. S., Wu, Y. L., Kudaba, I., Kowalski, D. M., Cho, B. C., Turna, H. Z., ... \& Kubota, K. (2019). Pembrolizumab versus chemotherapy for previously untreated, PD-L1-expressing, locally advanced or metastatic non-small-cell lung cancer (KEYNOTE-042): a randomised, open-label, controlled, phase 3 trial. The Lancet, 393(10183), 1819-1830.

11. Gandhi, L., Rodríguez-Abreu, D., Gadgeel, S., Esteban, E., Felip, E., De Angelis, F., ... \& Cheng, S. Y. S. (2018). Pembrolizumab plus chemotherapy in metastatic non-small-cell lung cancer. New England Journal of Medicine, 378(22), 2078-2092.

12. Paz-Ares, L., Luft, A. Vicente, D., Tafreshi, A., Gümüs, M., Mazières, J., .. \& Rodríguez-Cid, J. (2018). Pembrolizumab plus chemotherapy for squamous non-smallcell lung cancer. New England Journal of Medicine, 379(21), 2040-2051. 